\title{
PGLA/PEG Copolymer-Based Paclitaxel
}

National Cancer Institute

\section{Source}

National Cancer Institute. PGLA/PEG Copolymer-Based Paclitaxel. NCI Thesaurus. Code C71692.

A controlled-release, intratumoral paclitaxel formulation in which paclitaxel is incorporated into a thermosensitive, biodeg radable triblock copolymer consisting of poly(lactide-co-glycolide) (PLGA) and polyethylene glycol (PEG). Upon intratumoral injection, paclitaxel is released slowly and continuously into tumor tissues from the gelled thermosensitive triblock copolymer over a period of 4 to 6 weeks; in tumor cells, paclitaxel binds to tubulin and inhibits the disassembly-assembly dynamics of microtubules, resulting in cell cycle arrest and cell death. The thermosensitive triblock copolymer component of this formulation transforms from a water-soluble polymer at room temperature to a water-insoluble, biodegradable gel depot at body temperature; intratumoral controlled-release of paclitaxel from the gel minimizes systemic exposure to paclitaxel and the paclitaxel toxicity profile. 